\title{
STUDIES ON GANGRENE FOLLOWING COLD INJURY. III. EDEMA FOLLOWING COLD INJURY: ITS MAGNITUDE AND THE COMPOSITION AND SOURCES OF EDEMA FLUID ${ }^{1}$
}

\author{
By FREDERICK A. FUHRMAN ANd J. M. CRISMON \\ (From the Department of Physiology, Stanford Unizersity School of Medicinc, \\ Stanford University, California)
}

(Received for publication September 1, 1946)

One of the most prominent features of severe cold injury (frostbite) is the early and rapid development of edema of the injured part. We have described previously a method for the production of controlled injury by cold (1) and the general course of events ending in gangrene (2). The data presented here concern the edema following frostbite. Most of these observations were carried out during the first 24 hours after injury, at a time when swelling of the injured part occurs. The method used for the production of the injury by cold is the same as that described previously (1).

\section{A. Magnitude and location of edema}

The maximum increase in volume of ears and feet of rabbits following frostbite of different duration and at different temperatures is given in Table I. In ears the greater part of the fluid is found in the more distensible proximal part. The measurements were made by immersing as much as possible of the ear in water and measuring the volume of water displaced. In the leg most of the measurements were made as far proximally as the part was frozen (to the tuberosity at the base of the fifth metatarsal). The fluid, however, is not confined to this region, but is forced up the leg in a manner similar to that observed in ears. A few measurements of volume were made as far as the tuber calcanei (Table I). Twenty-four hours after injury of the foot, edema is apparent above the ankle and in some animals extends as far as the knee. Measurements of total fluid loss by estimation of the volume change of the entire leg were not made.

The appearance of the foot of a rabbit 2 hours after frostbite $\left(3\right.$ minutes at $-55^{\circ} \mathrm{C}$.) is shown

1 The work described in this paper was done under a contract, recommended by the Committee on Medical Research, between the Office of Scientific Research and Development and Stanford University.
TABLE I

Swelling of feet and ears following frostbite

\begin{tabular}{|c|c|c|c|c|c|}
\hline $\begin{array}{l}\text { Duration of } \\
\text { immersion }\end{array}$ & Temp. & $\begin{array}{c}\text { Initial } \\
\text { vol- } \\
\text { ume }\end{array}$ & $\begin{array}{c}\text { Maxi- } \\
\text { mum } \\
\text { vol- } \\
\text { ume }\end{array}$ & $\begin{array}{c}\text { In- } \\
\text { crease }\end{array}$ & $\frac{\text { Max. vol. }}{\text { Init. vol. }} \times 100$ \\
\hline $\begin{array}{c}\text { min. } \\
\text { Rabbit ears }\end{array}$ & ${ }^{\circ} \mathrm{C}$ & $m l$. & $m l$. & $m l$ & \\
\hline $1 \frac{1}{2}$ & -55 & $\begin{array}{l}7.5 \\
9.0\end{array}$ & $\begin{array}{l}36 \\
39\end{array}$ & $\begin{array}{l}28.5 \\
30\end{array}$ & $\begin{array}{l}480 \\
433\end{array}$ \\
\hline Rabbit feet & \multicolumn{5}{|c|}{$\begin{array}{l}\text { (Volume measured to base of } \\
\text { fif th metatarsal) }\end{array}$} \\
\hline 1 & -55 & $\begin{array}{l}12 \\
13 \\
13 \\
13 \\
14 \\
13 \\
12\end{array}$ & $\begin{array}{l}25 \\
33 \\
25 \\
31 \\
20 \\
28 \\
25\end{array}$ & $\begin{array}{r}13 \\
20 \\
12 \\
18 \\
6 \\
15 \\
13\end{array}$ & $\begin{array}{l}208 \\
254 \\
192 \\
238 \\
142 \\
215 \\
208\end{array}$ \\
\hline 2 & -55 & $\begin{array}{l}13 \\
13 \\
13 \\
12 \\
11\end{array}$ & $\begin{array}{l}36 \\
37 \\
25 \\
30 \\
31\end{array}$ & $\begin{array}{l}23 \\
24 \\
12 \\
18 \\
20\end{array}$ & $\begin{array}{l}277 \\
285 \\
192 \\
250 \\
282\end{array}$ \\
\hline 3 & -55 & $\begin{array}{l}12 \\
11 \\
12 \\
13 \\
14\end{array}$ & $\begin{array}{l}35 \\
30 \\
30 \\
35 \\
35\end{array}$ & $\begin{array}{l}23 \\
19 \\
18 \\
22 \\
21\end{array}$ & $\begin{array}{l}291 \\
273 \\
250 \\
269 \\
250\end{array}$ \\
\hline 3 & -15 & $\begin{array}{r}11 \\
9\end{array}$ & $\begin{array}{r}12 \\
9\end{array}$ & $\begin{array}{l}1 \\
0\end{array}$ & $\begin{array}{l}109^{*} \\
100^{*}\end{array}$ \\
\hline 3 & -25 & $\begin{array}{l}11 \\
10\end{array}$ & $\begin{array}{l}27 \\
30\end{array}$ & $\begin{array}{l}16 \\
20\end{array}$ & $\begin{array}{l}245 \\
300\end{array}$ \\
\hline 3 & -35 & $\begin{array}{l}13 \\
12\end{array}$ & $\begin{array}{l}31 \\
33\end{array}$ & $\begin{array}{l}18 \\
21\end{array}$ & $\begin{array}{l}239 \\
275\end{array}$ \\
\hline 3 & -45 & $\begin{array}{l}12 \\
11\end{array}$ & $\begin{array}{l}28 \\
30\end{array}$ & $\begin{array}{l}16 \\
19\end{array}$ & $\begin{array}{l}233 \\
273\end{array}$ \\
\hline 60 & -15 & $\begin{array}{l}12 \\
13 \\
13\end{array}$ & $\begin{array}{l}34 \\
32 \\
30\end{array}$ & $\begin{array}{l}22 \\
19 \\
18\end{array}$ & $\begin{array}{l}283 \\
246 \\
250\end{array}$ \\
\hline Rabbit feet & (Vo & lume $r$ & easure & d to tu & er calcanei) \\
\hline 3 & -55 & $\begin{array}{l}20 \\
17 \\
27\end{array}$ & $\begin{array}{l}65 \\
40 \\
75\end{array}$ & $\begin{array}{l}45 \\
23 \\
48\end{array}$ & $\begin{array}{l}325 \\
235 \\
277\end{array}$ \\
\hline
\end{tabular}

* Freezing did not occur. 



Fig. 1. Edema of Rabbit Feet Following Severe Cold Ixjury

$\mathrm{A}, \mathrm{B}$ and $\mathrm{C}$ show a right hind foot, with hair removed, before cold injury. D, E and $\mathrm{F}$ show the same foot 2 hours after injury by immersion for 3 minutes at $-50^{\circ} \mathrm{C}$. Foot immersed to the point indicated by the ink line. Volume of edematous foot is 2.7 times that of the foot before injury.

in Figure 1. The toes are spread apart by the accumulation of fluid, and swelling is especially marked on the dorsal surface of the foot. Much less swelling is evident on the plantar surface where the skin is much more tightly bound to the underlying connective tissue. Upon incision of the dorsum of an edematous foot, the edema fluid may be seen to be distributed chiefly in the loose connective tissue underlying the skin. The fluid itself is viscous and drains slowly from the incision. It coagulates within a few minutes after withdrawal from the foot.
In order to determine whether any exudation of fluid occurred in the proximal, uninjured portion of a frostbitten ear, the distal, frostbitten part was amputated after injury in one experiment. Following frostbite for 90 seconds at $-55^{\circ}$ C. a clamp was placed on the ear just proximal to the line of immersion. Two and one-half hours later the ear clistal to the clamp was amputated, cauterized, and the clamp then released. On the following day there was very slight edema present in the distal part of the stump near the site of amputation. This had disappeared on the second day. No 
edema approaching in magnitude that occurring after untreated frostbite was observed, and no evidence of edema was seen in the proximal part of the ear. It thus appears that the fluid loss occurs only in the distal injured part of the ear and that edema proximal to the frostbitten region is the result of forcing of fluid into that region after the limit of distensibility of the tip of the ear is reached.

\section{B. Rate of swelling}

In all animals in which the foot or ear actually became frozen during immersion (true frostbite), thawing and return of blood to the injured extremity were followed immediately by rapid and extensive swelling. Increase in the volume of a frostbitten foot could usually be demonstrated 20 minutes after injury. The relative increase in volume of feet frostbitten for 1,2 , and 3 minutes at $-55^{\circ} \mathrm{C}$. may be compared in Figure 2, in which the maxima and minima for each duration of injury are plotted at various time intervals after frostbite. The volume was measured to the line of immersion (the tuberosity at the base of the fifth metatarsal).

If comparisons are made between rabbit feet immersed at $-55^{\circ} \mathrm{C}$. for 1,2 , and 3 minutes, it is found that the rate of swelling increases with the duration of immersion and thus also with the severity of the injury. Although swelling begins within 20 to 30 minutes after exposure in all cases, it occurs most rapidly following 3-minute exposure and least rapidly after a 1 -minute exposure. Following 1-minute immersion the maximum volume is reached in from 3 to 6 hours after injury. Following a 2-minute immersion the maximum occurs somewhat earlier, and after 3minute immersion the maximum volume is attained in 1 to 2 hours in some animals. The maximum volume attained is similar following the different periods of immersion, although some feet showed only slight increase in volume following 1-minute exposure and others became as swollen as those exposed for 3 minutes. The great variability of the foot volume following 1 -minute exposure (Figure 2) is an indication of lack of

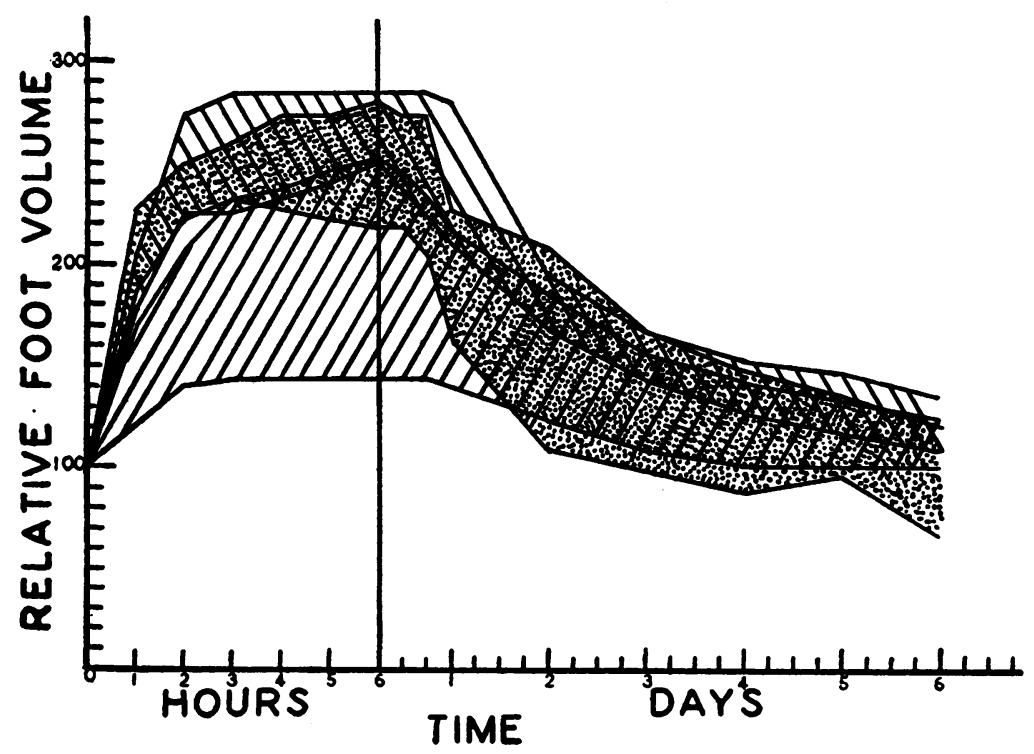

Fig. 2. Comparison of Volume Changes in Rabbit Feet after Exposure at $-55^{\circ}$ C. For One, Two, and Three Minutes

Initial foot volume expressed as 100 . For each severity of injury the maximum and minimum values of foot volume at different time periods after injury are connected by straight lines. The area between the curves of maximum and minimum volume include all of the cases measured. Area shaded right-1-minute immersion. Area shaded left-2-minute immersion. Area spotted-3-minute immersion. 
uniformity in injury following this length of immersion.

The decrease in foot volume begins about 1 day after injury and appears to be more rapid following the more severe injury. This decrease in volume results from dehydration of the foot, due to loss of fluid to the outside as well as internally. The external water loss is most rapid when necrosis and wet gangrene appear, and, since necrosis of most of the injured area is an invariable consequence of a 3 -minute immersion at $-55^{\circ} \mathrm{C}$., drying and shrinkage of the foot below its normal size are most rapid in this type of injury.

\section{Subcutaneous tissue pressure}

Subcutaneous tissue pressures in frostbitten feet were determined at varying times after injury by the method of Henderson (3) as modified by Wells, Youmans, and Miller (4). The needle was inserted through the skin on the dorsal surface of the foot into the edematous mass of underlying tissue, and the point adjusted so that it was approximately midway between the skin and metatarsal bones. Care was taken that only two punctures were made in each foot; repeated puncturing of the skin resulted in loss of fluid through the skin and consequent decrease in pressure.

The results of determinations of subcutaneous tissue pressure in the frostbitten feet of 9 animals

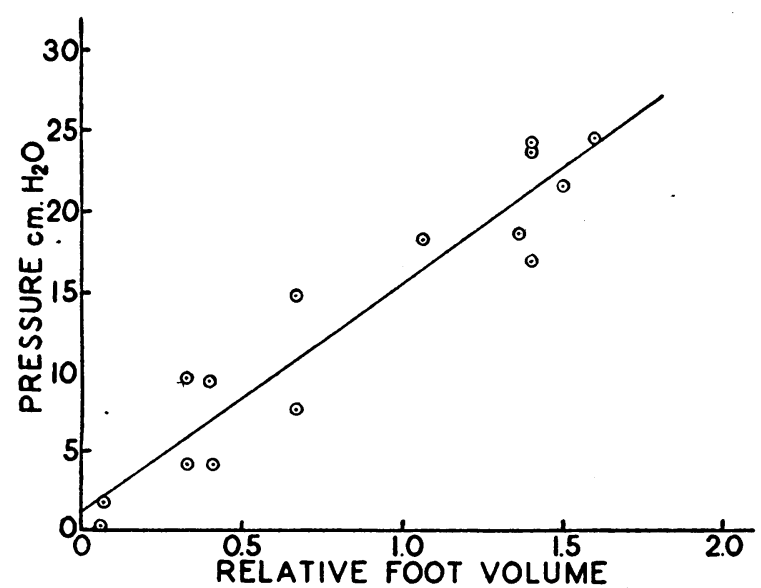

Fig. 3. Relationship Between foot Volume and Subcutaneous Tissue Pressure after Frostbite

Subcutaneous tissue pressure in $\mathrm{cm} . \mathrm{H}_{2} \mathrm{O}$ plotted as a function of relative increase in foot volume after exposure of one foot at $-55^{\circ} \mathrm{C}$. for 3 minutes. Data from 9 animals. A maximum of two determinations was made on each animal. are plotted against the foot volume at the time of pressure measurement in Figure 3. In all cases the frostbite was produced by immersion at $-55^{\circ} \mathrm{C}$. for 3 minutes. The line drawn in Figure 3 was fitted to the data by the method of least squares and may be represented by the equation

$$
P=1.12+0.144 V
$$

in which $P$ is subcutaneous pressure in $\mathrm{cm}$. of water and $V$ is the relative increase in foot volume.

It may be seen from Figure 3 that as the volume of the foot increases the pressure is found to increase until, at maximum foot volume, the subcutaneous pressure is approximately $25 \mathrm{~cm}$. $\mathrm{H}_{2} \mathrm{O}$. This pressure is of the same order of magnitude as the pressure inside capillaries. Landis $(5,6)$ found by direct measurement that the capillary pressures of arteriolar and venous capillaries were $30 \mathrm{~cm} . \mathrm{H}_{2} \mathrm{O}$ and $17 \mathrm{~cm} . \mathrm{H}_{2} \mathrm{O}$ respectively in the mesentery of the rat and 38.5 $\mathrm{cm} . \mathrm{H}_{2} \mathrm{O}$ and $17 \mathrm{~cm} . \mathrm{H}_{2} \mathrm{O}$ in the mesentery of the guinea pig. The importance of high subcutaneous pressure in relation to the functional pathology of frostbite will be discussed later.

When the foot has attained a volume 250 to 300 per cent of the initial volume, further increase measured to the line of immersion does not occur, but the pressure within the foot reaches such a level that fluid is forced in a proximal direction above the level of injury.

If the time course of increase in subcutaneous pressure in the foot following cold injury is considered, it is found that the pressure increases during the period of swelling (for the first 4 to 6 hours), and then reaches a maximum pressure coinciding in time with the maximum foot volume.

\section{Composition of edema fluid}

Determination of the protein concentration of edema fluid withdrawn from frostbitten feet and in fluid drawn from blisters on frostbitten ears was made at various times after frostbite. The protein concentration was calculated from the specific gravity of the fluid determined by the falling drop method (7). Protein concentration was calculated from the formula given by Weech (8) :

$$
\operatorname{Pr}=(\text { Sp. Gr. }-1.0069) \times 340.1
$$


in which $\operatorname{Pr}$ is the protein concentration in grams per $100 \mathrm{ml}$.

\section{Protein concentration of ear blister fluid}

The protein concentration of blister fluid from frostbitten ears, withdrawn at various times after frostbite of 90 -second duration at $-55^{\circ} \mathrm{C}$., is given in Figure 4 . In the greater number of these animals the blisters formed in the first 4 hours after injury, although in some cases blisters were not seen until 8 to 12 hours after injury. Fluid from the blisters was straw-colored and did not contain appreciable amounts of hemoglobin. It may be seen from the figure that there is a decrease in protein concentration of blister fluid with time. The line drawn in the figure, fitted to the data by the method of least squares, may be represented by the equation

$$
\operatorname{Pr}=4.303-0.0254 t
$$

in which $\mathrm{Pr}$ is the protein concentration in grams per $100 \mathrm{ml}$. and $t$ is the time in hours after frostbite. The coefficient of correlation between protein concentration and time after frostbite was calculated to be -0.798 .

Pochin (9) found a negative correlation between protein concentration and time after injury in edema fluid taken from rabbit ears following vascular occlusion. The initial protein concentration of the edema fluid after vascular occlusion and of blister fluid after frostbite injury are very



Fig. 4. Time Course of Change in Protein Concentration of Ear Blister Fluid Following Severe Cold INJURY

Data from 12 animals. Frostbite was produced in all cases by immersion at $-55^{\circ} \mathrm{C}$. for 90 seconds.
TABLE II

Protein concentration in edema fluid from frostbitten feet Exposure at $-55^{\circ} \mathrm{C}$.

\begin{tabular}{c|c|c|c|c}
\hline \hline $\begin{array}{c}\text { No. of } \\
\text { animals }\end{array}$ & $\begin{array}{c}\text { Duration } \\
\text { of } \\
\text { exposure }\end{array}$ & $\begin{array}{c}\text { Time after frostbite } \\
\text { at which fluid was } \\
\text { sampled }\end{array}$ & $\begin{array}{c}\text { Mean } \\
\text { protein }\end{array}$ & $\begin{array}{c}\text { S. E. of } \\
\text { mean }\end{array}$ \\
\hline & & $120-240$ minutes & $\begin{array}{c}\text { per cent } \\
3.46\end{array}$ & .668 \\
5 & 1 & $\begin{array}{c}\text { 90-240 minutes } \\
22\end{array}$ & 3.13 & .139 \\
4 & 3 & 24 hours & 3.01 & .323 \\
4 & 3 & 44 hours & 3.91 & .585 \\
\hline
\end{tabular}

similar ( 4.5 per cent and 4.3 per cent respectively). Pochin's data show a more rapid decrease in protein concentration in the edema fluid after occlusion than that reported here in blister fluid after frostbite. This may indicate a more rapid removal of protein-containing fluid via the lymphatics in occlusion.

\section{Protein concentration of foot edema fluid}

The protein concentration of edema fluid taken from frostbitten feet under various circumstances is given in Table II. It may be seen from the table that the protein concentration after 1-minute frostbite is somewhat less than after 3-minute frostbite at $-55^{\circ} \mathrm{C}$. This difference is, however, not significant $(P<0.7)$.

The data for the protein.concentration of foot edema fluid taken at different times after injury are not sufficient to establish so definite a relationship as that in ear blister fluid. The correlation between protein concentration and time in hours after injury was -0.494 and the straight line fitted to the data may be represented by the equation

$$
\operatorname{Pr}=4.326-0.052 t
$$

in which the symbols are the same as those used in equation (3). This relationship is based upon 22 determinations made between 1 and 6 hours after injury and upon 4 determinations made 24 hours after frostbite. It is apparent that in frostbitten feet, as in frostbitten ears, the protein concentration of the edema-fluid is initially high, only slightly below that of the plasma, and that it decreases progressively with time after injury.

Table II also shows the protein concentration of foot edema fluid taken 44 hours after frostbite. In this case there was an apparent increase in protein concentration. It seems probable that this 
increase is due to loss of water more rapid than loss of protein from the foot.

The protein concentration found in the foot edema fluid and in ear blister fluid following cold injury is in good agreement with the data reported by Harkins and Harmon (10) for protein concentration in edema fluid from severely frostbitten dogs. They report a mean edema fluid protein concentration of 3.6 per cent.

\section{Effect of edema fluid upon blood pressure and isolated smooth muscle.}

The frequent reports of the presence of a toxic substance in plasma and edema fluid after burns $(11,12)$ suggest that such toxic materials may be present in the edema fluid taken from extremities following cold injury. In order to test this possibility, edema fluid removed from frostbitten rabbit feet 2 hours after injury was examined in the following manner.

a. Effect upon blood pressure. Edema fluid was withdrawn from the feet of two rabbits 85 and 95 minutes after frostbite. In one case the fluid was used immediately and in the other it was held overnight in a refrigerator. This fluid was then injected intravenously into rabbits anesthetized with dial. Arterial pressure was recorded during and following the injection. Injection of the edema fluid in amounts up to $2 \mathrm{ml}$. in a rabbit weighing $2.4 \mathrm{kgm}$. produced no change in the level of arterial pressure.

b. Effect upon isolated guinea pig intestine. Segments of guinea pig ileum were suspended in oxygenated Tyrode solution containing $1: 1,000,000$ atropine. Addition of edema fluid withdrawn from frostbitten rabbit feet produced slight contraction in one instance. In this case 1.0 $\mathrm{ml}$. of edema fluid was equal in activity to $0.1 \mu \mathrm{g}$. histamine. This activity may be accounted for entirely on the basis of the normal histamine content of the small amounts of blood present in the edema fluid, since rabbit blood contains 10 to $12 \mathrm{~kg}$. histamine per $\mathrm{ml}$. (13). In all muscle preparations the activity of the muscle was confirmed by contraction in response to additions of histamine.

c. Assay of edema fluid for histamine. Edema fluid withdrawn from frostbitten feet 2 to 4 hours after injury was prepared for histamine assay by the method of Barsoum and Gaddum (13) as modified by Anrep et al. (14). The extracts were tested upon the atropinized guinea pig ileum and upon atropinized rectal caecum of the fowl. No contractions of the isolated muscle were produced by the edema fluid extracts. Comparison with known concentrations of histamine showed that the histamine content of the edema fluid must be less than $0.2 \mu \mathrm{g}$. per ml. of original edema fluid.

d. Intradermal injection of edema fluid. Edema fluid from a rabbit foot, withdrawn 95 minutes after injury, was injected intradermally into the ears of two rabbits. The volumes injected were approximately 0.1 and $0.3 \mathrm{ml}$. Slight vasodilatation was seen immediately surrounding the sites of injection within 5 minutes. No edema developed and the slight hyperemia disappeared within 12 hours.

Histamine liberation from perfused limbs injured by high temperature has been described by Kellaway and Rawlinson (15). The edema fluid formed after frostbite, however, does not contain significant amounts of histamine. Failure to demonstrate the presence of toxic materials in this edema fluid by the methods outlined above is not interpreted to mean that chemical substances are not implicated in the local changes following frostbite. It is possible that such principles as those described by Shorr, Zweifach and Furchgott (16), which would not be detected by the methods used here, may play a part in the local circulatory changes following cold injury.

\section{E. Changes in blood composition coincidental with swelling}

\section{Plasma protein changes following cold injury.}

Plasma protein concentration was calculated from the plasma specific gravity, determined by the falling drop method of Barbour and Hamilton (7), by means of equation (2). In every case the plasma protein concentration decreased during the period of swelling of the frostbitten foot. The results obtained in a representative experiment are shown in Figure 5 (which also shows changes in foot volume, hematocrit, hemoglobin concentration, and blood specific gravity during the same time period). In this experiment the plasma protein concentration fell from an initial value of 5.34 per cent to a minimum of 3.96 per cent. Similar results were obtained in 13 other animals in which the plasma protein fell to 81.3 per cent of the initial 185 to 357 minutes after injury. Plasma protein concentrations before frostbite and at times ranging from 160 to 357 minutes after frostbite in 6 animals are given in Table III. It may be seen that in all cases there is a decrease in plasma protein concentration following frostbite, ranging from 0.98 to 1.57 grams per $100 \mathrm{ml}$. The relationship between the decrease in plasma protein concentration and the protein concentration in edema fluid will be considered below. 

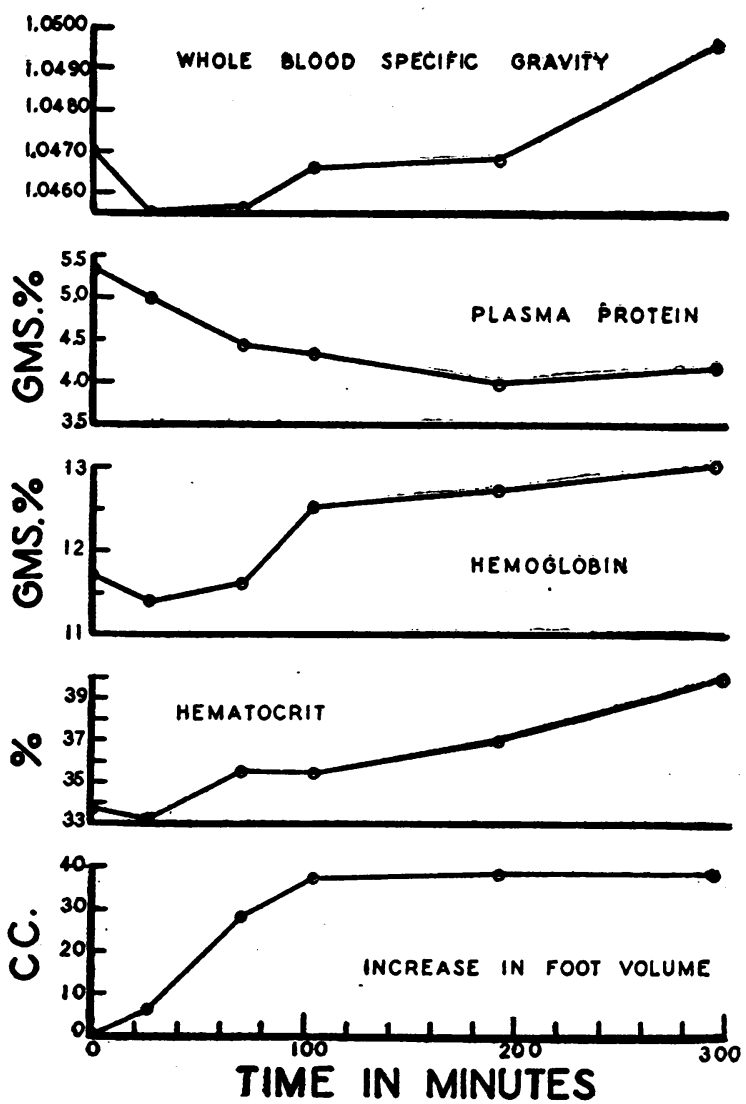

Fig. 5. Time Course of Changes in Whole Blood Specific Gravity, Plasma Protein, Hemoglobin, Hematocrit and Foot Volume Following Severe Cold InJURY

Representative data from one animal after exposure of one hind foot at $-55^{\circ} \mathrm{C}$. for 3 minutes.

In order to determine the approximate duration of the decrease in plasma protein concentration following this type of frostbite, determina-

TABLE III

Plasma protein changes following cold injury 3 -minute immersion of foot at $-55^{\circ} \mathrm{C}$.

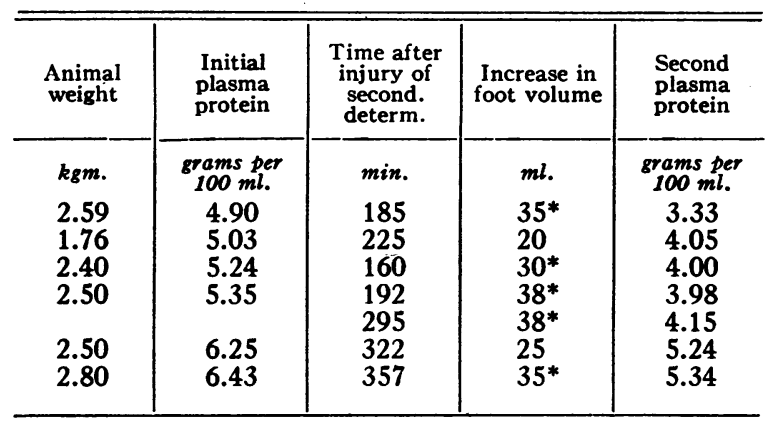

* Volume increase measured to the tuber calcanei.
TABLE IV

Plasma protein concentration one day after frostbite

Feet exposed at $-50^{\circ} \mathrm{C}$. to $-54^{\circ} \mathrm{C}$. for 3 minutes

\begin{tabular}{c|c|c|c}
\hline $\begin{array}{c}\text { Initial plasma } \\
\text { protein }\end{array}$ & $\begin{array}{c}\text { Time after } \\
\text { frostbite }\end{array}$ & $\begin{array}{c}\text { Plasma } \\
\text { protein }\end{array}$ & Difference \\
\cline { 2 - 3 } $\begin{array}{c}\text { grams per } \\
100 \mathrm{ml} .\end{array}$ & hours & $\begin{array}{c}\text { grams per } \\
100 \mathrm{ml} .\end{array}$ & \\
4.83 & 23 & 4.69 & -0.14 \\
4.60 & 24 & 4.15 & -0.45 \\
4.00 & 24 & 3.81 & -0.19 \\
4.63 & 24 & 4.76 & +0.13 \\
\hline
\end{tabular}

tions were made 24 hours after injury in four animals. The results are given in Table IV. It is clear from the data given in the table that after this length of time the plasma protein concentration had returned to approximately the initial value. The data show no tendency toward a decrease in plasma protein concentration such as might result from leakage of protein into regions remote from the site of injury.

\section{Relationship of plasma protein changes to edema fluid protein concentration}

Information regarding the origin of the edema fluid in frostbitten extremities may be obtained by comparison of the protein content of the edema fluid with the plasma protein concentration before and after injury. Such a comparison has been made for the data given here on two bases: (1) comparison of the mean protein concentration of the edema fluid with the mean initial plasma protein concentration; (2) comparison, in individual animals, of the loss in total circulating protein with the total protein found in edema fluid.

Determination of the initial plasma protein concentration (before frostbite) in 23 animals gave a mean value of 5.42 grams per $100 \mathrm{ml}$. (Range 4.00 to 6.56 ; S.E. of mean $=0.137$ ). The protein concentration of edema fluid taken from frostbitten feet and from blisters on frostbitten ears during the first few hours after injury were given previously as 4.13 grams per $100 \mathrm{ml}$. and 4.23 grams per $100 \mathrm{ml}$. respectively. If these values for protein concentration in the edema fluid are compared directly with the mean plasma protein concentration it may be calculated that for feet 76.2 per cent or for ears 78.0 per cent of the edema fluid is whole plasma and 
TABLE $V$

Protein content of edema fluid

Calculated data derived from experimental data in preceding table

\begin{tabular}{|c|c|c|c|c|c|c|}
\hline 1 & 2 & 3 & 4 & 5 & 6. & 7 \\
\hline \multirow{2}{*}{$\begin{array}{l}\text { Animal } \\
\text { weight }\end{array}$} & \multirow{2}{*}{$\begin{array}{l}\text { Calc.* } \\
\text { plasma } \\
\text { volume }\end{array}$} & \multirow{2}{*}{$\begin{array}{c}\text { Foot } \\
\text { volume } \\
\text { increase }\end{array}$} & \multirow{2}{*}{$\begin{array}{c}\text { Decrease } \\
\text { in plasma } \\
\text { protein } \\
\text { (deter- } \\
\text { mined) }\end{array}$} & \multirow{2}{*}{$\begin{array}{c}\text { Grams } \\
\text { protein } \\
\text { lost }\end{array}$} & \multicolumn{2}{|c|}{$\begin{array}{l}\text { Protein conc. of } \\
\text { edema fluid }\end{array}$} \\
\hline & & & & & $\begin{array}{l}\text { Theo- } \\
\text { retical }\end{array}$ & $\begin{array}{c}\text { Ob- } \\
\text { served }\end{array}$ \\
\hline kgm. & ml. & $m l$. & $\begin{array}{c}\text { grams per } \\
100 \mathrm{ml} .\end{array}$ & & \multicolumn{2}{|c|}{ grams per $100 \mathrm{ml}$} \\
\hline 2.59 & 103.6 & 35 & 1.57 & 1.63 & 4.66 & 3.6 \\
\hline 1.76 & 70.4 & 20 & .98 & .69 & 3.45 & . \\
\hline 2.40 & 96.0 & 30 & 1.24 & 1.19 & 3.97 & 3.8 \\
\hline 2.50 & $\begin{array}{l}100.0 \\
100.0\end{array}$ & $\begin{array}{l}38 \\
38\end{array}$ & $\begin{array}{l}1.37 \\
1.20\end{array}$ & $\begin{array}{l}1.37 \\
1.20\end{array}$ & $\begin{array}{l}3.61 \\
3.16\end{array}$ & 3.1 \\
\hline 2.50 & 100.0 & 25 & 1.01 & 1.01 & 4.04 & 4.3 \\
\hline 2.80 & 112.0 & 35 & 1.09 & 1.22 & 3.49 & 5.3 \\
\hline
\end{tabular}

* Four per cent of body weight.

the remainder must therefore be plasma ultrafiltrate.

The data given in Table III make it possible to calculate, for individual animals, the loss of total circulating protein as compared with protein in edema fluid from the foot of the same animal. In Table III are given the initial plasma protein concentration, and, after 160 to 357 minutes, the increase in foot volume and the plasma protein concentration at that time. In Table $\mathrm{V}$ are listed certain derived data from Table III, as well as the actual protein concentration of the foot edema fluid from these animals. The normal plasma volume of these animals is assumed to be four per cent of the body weight. It may be seen that the loss in total circulating protein ranges from 0.69 to 1.63 grams if it be assumed that no change in plasma volume occurs (Column 5). When this is divided by the volume of fluid measured to have accumulated in the foot during the time period given (Column 3 ), the theoretical protein concentration of the edema fluid may be calculated (Column 6). Good agreement is seen between this theoretical value and that actually determined (Column 7), indicating that the total loss of circulating protein may be accounted for by protein occurring in the edema fluid. It should be pointed out that this comparison involves, at best, a rough approximation of the actual changes. The determination of the exact volume of edema fluid cannot be made with great accuracy by the displacement method. Furthermore the assumption that no change in plasma volume occurs is not strictly valid, since data presented below indicate a reduction in plasma volume soon after injury, with a progressive replacement in plasma volume over a period of several hours.

\section{Changes in hemoglobin concentration and hematocrit during swelling.}

The hemoglobin concentration and the hematocrit were determined in arterial blood during the period of swelling of the foot following a 3minute immersion at $-55^{\circ} \mathrm{C}$.

The procedure was as follows: Heparin was used as an anticoagulant. Hemoglobin was determined by the acid hematin method using $0.05 \mathrm{ml}$. of blood. Hematocrit was determined in Van Allen tubes without dilution of the blood. In several animals the hematocrit was calculated from the hemoglobin concentration using a value of 33.9 grams hemoglobin per $100 \mathrm{ml}$. of packed erythrocytes (17). This was calculated assuming an oxygen capacity of $46.1 \mathrm{ml}$. of oxygen per $100 \mathrm{ml}$. packed cells (17) and $1.36 \mathrm{ml}$. oxygen to be bound by 1 gram hemoglobin (18). In a limited number of determinations on rabbit blood the mean corpuscular hemoglobin concentration was found to be 33.6 grams per $100 \mathrm{ml}$. of packed erythrocytes.

For the four animals in which both hemoglobin and hematocrit were determined on the same samples of blood, the mean corpuscular hemoglobin concentration was calculated for the initial sample and the sample taken at the time of attainment of maximum foot volume. It was found that a decrease occurred in two animals ( 34.7 to 32.8 and 35.3 to 33.5 ) and no change occurred in the other two. Since the difference found was not great and appeared in only two of four animals, swelling of erythrocytes during the development of edema is not considered to be an important or invariable consequence of cold injury under the conditions used here.

The hemoglobin and hematocrit values, together with the figures showing fluid loss to the injured foot and the whole blood specific gravity, are given in Table VI. As is to be expected from data given previously which indicated loss of about 77 per cent whole plasma, the hemo- 
TABLE VI

Changes in hemoglobin concentration and hematocrit following frostbite of rabbits' feet

Feet exposed at $-55^{\circ} \mathrm{C}$. for 3 minutes

\begin{tabular}{|c|c|c|c|c|c|}
\hline$\underset{\text { number }}{\text { Animal }}$ & $\begin{array}{c}\text { Time } \\
\text { after } \\
\text { frostbite }\end{array}$ & $\begin{array}{l}\text { Increase } \\
\text { in foot } \\
\text { volume }\end{array}$ & $\begin{array}{l}\text { Whole } \\
\text { blood } \\
\text { spec. gr. }\end{array}$ & $\begin{array}{l}\text { Hemo- } \\
\text { globin }\end{array}$ & $\underset{\text { crit }}{\text { Hemato- }}$ \\
\hline & $\min$. & $m l$. & & $\begin{array}{l}\text { grams per } \\
100 \mathrm{ml} .\end{array}$ & per cent \\
\hline 45 & $\begin{array}{r}0 \\
26 \\
70 \\
104 \\
192 \\
295\end{array}$ & $\begin{array}{r}0 \\
6 \\
28 \\
37 \\
38 \\
38\end{array}$ & $\begin{array}{l}1.0470 \\
1.0455 \\
1.0456 \\
1.0466 \\
1.0468 \\
1.0495\end{array}$ & $\begin{array}{l}11.7 \\
11.4 \\
11.6 \\
12.5 \\
12.7 \\
13.0\end{array}$ & $\begin{array}{l}33.7 \\
33.2 \\
35.5 \\
35.4 \\
36.9 \\
39.7\end{array}$ \\
\hline 3 & $\begin{array}{r}0 \\
76 \\
183 \\
316\end{array}$ & $\begin{array}{r}0 \\
18 \\
22 \\
23\end{array}$ & $\begin{array}{l}1.0560 \\
1.0570 \\
1.0580 \\
1.0576\end{array}$ & $\begin{array}{l}14.1 \\
14.9 \\
16.4 \\
16.1\end{array}$ & $\begin{array}{l}41.5^{*} \\
47.5^{*}\end{array}$ \\
\hline 13 & $\begin{array}{r}0 \\
37 \\
68 \\
174 \\
223\end{array}$ & $\begin{array}{r}0 \\
6 \\
10 \\
15 \\
18\end{array}$ & $\begin{array}{l}1.0550 \\
1.0554 \\
1.0564 \\
1.0577 \\
1.0569\end{array}$ & $\begin{array}{l}14.3 \\
14.8 \\
15.8 \\
16.1 \\
15.4\end{array}$ & $42.5^{*}$ \\
\hline 7 & $\begin{array}{r}0 \\
203 \\
246\end{array}$ & $\begin{array}{r}0 \\
15 \\
16\end{array}$ & $\begin{array}{l}1.0599 \\
1.0619 \\
1.0622\end{array}$ & $\begin{array}{l}16.8 \\
17.3 \\
17.4\end{array}$ & $\begin{array}{l}49.5^{*} \\
51.5^{*}\end{array}$ \\
\hline 19 & $\begin{array}{r}0 \\
216\end{array}$ & $\begin{array}{r}0 \\
21\end{array}$ & $\begin{array}{l}1.0504 \\
1.0510\end{array}$ & $\begin{array}{l}11.6 \\
13.5\end{array}$ & $\begin{array}{l}35.0 \\
41.0\end{array}$ \\
\hline $17-s$ & $\begin{array}{r}0 \\
190\end{array}$ & $\begin{array}{r}0 \\
30\end{array}$ & $\begin{array}{l}1.0495 \\
10495\end{array}$ & $\begin{array}{l}11.8 \\
12.9\end{array}$ & $\begin{array}{l}36.0 \\
38.5\end{array}$ \\
\hline 6-s & $\begin{array}{r}0 \\
200\end{array}$ & $\begin{array}{r}0 \\
36\end{array}$ & $\begin{array}{l}1.0533 \\
1.0521\end{array}$ & $\begin{array}{l}13.6 \\
14.3\end{array}$ & $\begin{array}{l}38.5 \\
42.7\end{array}$ \\
\hline
\end{tabular}

Number 45, 17, 6: Foot volume measured to tuber calcanei.

* Hematocrit calculated from hemoglobin (see text).

$\mathrm{s}=$ spleen removed from circulation before frostbite.

globin concentration and hematocrit are found to increase progressively during the period of swelling. These values are plotted in Figure 5 for one representative animal.

From a comparison of the initial and final hematocrit values, provided the loss of fluid to the injured foot is known, it is possible to calculate the extent to which plasma volume, reduced due to loss into the injured region, has been replaced by withdrawal of fluid from extravascular sources. These data are shown in Table VII. The cell volume is assumed to remain constant throughout the experiment. In two animals (Nos. 17 and 6) the spleen was excluded from the circulation before frostbite in order to exclude the addition of cells from this source. These animals did not appear to differ from the others in the series.
TABLE VII

Calculations showing estimated replacement of plasma volume following severe cold injury See text for calculations and meanings of symbols used

\begin{tabular}{|c|c|c|c|c|c|c|c|}
\hline Animal number.$\ldots \ldots \ldots$ & 45 & 3 & 13 & 7 & 19 & $17 *$ & 6* \\
\hline 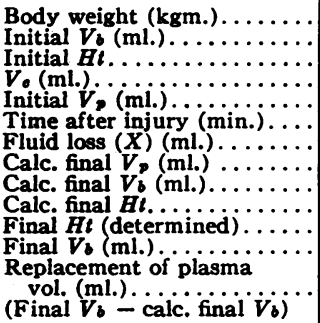 & $\begin{array}{r}2.50 \\
175 \\
33.7 \\
59 \\
116 \\
295 \\
38 \\
78 \\
137 \\
43.1 \\
39.7 \\
149 \\
12\end{array}$ & $\begin{array}{r}2.66 \\
186 \\
41.5 \\
77 \\
109 \\
316 \\
33 \\
76 \\
153 \\
50.4 \\
47.5 \\
162 \\
9\end{array}$ & $\begin{array}{r}2.85 \\
199 \\
42.5 \\
85 \\
114 \\
223 \\
24 \\
90 \\
175 \\
48.3 \\
45.6 \\
185 \\
10\end{array}$ & \begin{tabular}{|r|}
2.85 \\
199 \\
49.5 \\
97 \\
102 \\
246 \\
23 \\
79 \\
176 \\
55.4 \\
51.5 \\
189 \\
13
\end{tabular} & $\begin{array}{r}2.20 \\
154 \\
35.0 \\
54 \\
100 \\
216 \\
30 \\
70 \\
124 \\
43.6 \\
41.0 \\
132 \\
8\end{array}$ & $\begin{array}{r}2.50 \\
175 \\
36.0 \\
63 \\
112 \\
190 \\
30 \\
82 \\
145 \\
43.5 \\
38.5 \\
164 \\
19\end{array}$ & $\begin{array}{r}3.20 \\
224 \\
38.5 \\
86 \\
138 \\
200 \\
36 \\
102 \\
188 \\
45.8 \\
42.7 \\
202 \\
14\end{array}$ \\
\hline
\end{tabular}

* Spleen occluded from the circulation before cold injury.

For Table VII the calculations involved are as follows : initial blood volume (Initial $V_{b}$ ) is assumed to be 7 per cent of the body weight, from which is calculated the initial cell volume $\left(V_{c}\right)$ and the initial plasma volume (Initial $V_{p}$ ) by use of the hematocrit determined initially (Initial $H t$ ).

$$
V_{\mathrm{c}}=(\text { Body weight } \times 0.07) \times \text { Initial }^{4} \mathrm{Ht}
$$

Initial $V_{p}=($ Body weight $\times 0.07) \times(100-$ Initial $H t)$

If it be assumed that the fluid lost $(X)$ into the injured region is plasma and that the plasma volume is reduced by the amount $(X)$, then the following calculated values may be derived:

$$
\begin{aligned}
& \text { Calc. Final } V_{p}=\text { Initial } V_{p}-X \\
& \text { Calc. Final } V_{b}=\text { Cal. Final } V_{p}+V_{c} \\
& \text { Calc. Final } H t=\frac{V_{c} \times 100}{\text { Calc. Final } V_{b}}
\end{aligned}
$$

If, now, the final determined hematocrit value (Final $H t$ ) be compared in each case with the final calculated hematocrit (Calc. Final $H t$ ), it is found that the determined hematocrit value is smaller in all the animals. This indicates that part of the plasma lost has been replaced by water withdrawn from the interstitial compartment and from the gut. The extent of this replacement may be estimated by calculation of the blood volume on the basis of the determined final hematocrit (Final $H t$ ) and comparison of this figure with the calculated final blood volume (Calc. Final $V_{b}$ ) derived above.

$$
\text { Final } V_{b}=\frac{\text { Calc. Final } H t \times \text { Calc. Final } V_{b}}{\text { Final } H t}
$$

It is found (Table VII) that the replacement of plasma volume amounts to from 8 to $19 \mathrm{ml}$. in the time interval studied.

An examination of the hematocrit values following cold injury thus indicates a reduction in plasma volume which is partially replaced by extravascular fluid within a few hours. Further evidence for this is given in the next section. 


\section{Measurement of plasma volume following cold injury}

In four animals the plasma volume was determined by the dye method immediately before frostbite and again after 2 to 4 hours. Preliminary experiments showed that intravenously injected T-1824 was readily lost from the circulation into the injured foot, so that the frostbitten foot must be excluded from the circulation before the second plasma volume determination is made in order to obviate fictitiously high values.

The procedure was as follows: Initial plasma volume was determined by the intravenous administration of 2 mgm. per $\mathrm{kgm}$. T-1824; the determination of the dye concentration in plasma was made after 10 minutes (19). Plasma volume after frostbite was determined after first occluding the circulation to the injured foot by a tourniquet placed just above the knee. A blood sample was then withdrawn to serve as a control, an additional injection of $1 \mathrm{mgm}$. per $\mathrm{kgm}$. T-1824 was made intravenously, and the dye concentration again was determined after 10 minutes. Concentrations of $\mathrm{T}-1824$ were determined in undiluted plasma using a $620 \mu \mathrm{m}$. filter in a Klett-Summerson photoelectric colorimeter.

Table VIII shows the results of determinations of initial plasma volume and plasma volume after frostbite of one hind foot at $-55^{\circ}$ C. for 3 minutes. It will be seen that the determinations made 120,148 , and 180 minutes after injury all show reductions in plasma volume, but that after 240 minutes (in one animal) the plasma volume is made up to its initial value. These results confirm those obtained by calculation of hematocrit differences in showing that the fluid lost from the plasma is rapidly replaced during the first few hours after injury.

\section{TABLE VIII}

Plasma volume before and after severe cold injury

Plasma volume was determined by the use of T-1824 as described in the text

\begin{tabular}{|c|c|c|c|c|}
\hline Animal number. & 82-B & 12 & 82 & 79 \\
\hline $\begin{array}{l}\text { Weight (kgm.) } \ldots \ldots \ldots \ldots \\
\text { Initial hematocrit } \ldots \ldots \ldots \ldots \\
\text { Final hematocrit. } \ldots \ldots \ldots \\
\text { Time after injury of second } \\
\quad \text { plasma volume measurement } \\
\text { (min.) } \\
\text { Increase in foot volume }(\mathrm{ml} .) \ldots \\
\text { Initial plasma volume }(\mathrm{ml} .) \ldots \\
\text { Final plasma volume }(\mathrm{ml} .) \ldots \ldots \\
\text { Difference (ml.) } \ldots \ldots \ldots \ldots \ldots \ldots\end{array}$ & $\begin{array}{r}120 \\
28 \\
172 \\
143 \\
-29\end{array}$ & $\begin{array}{r}4.044 \\
43 \\
49 \\
\\
148 \\
27 \\
183 \\
117 \\
-66\end{array}$ & $\begin{array}{r}180 \\
38 \\
156 \\
125 \\
-31\end{array}$ & $\begin{array}{r}240 \\
20 \\
97 \\
98 \\
+1\end{array}$ \\
\hline
\end{tabular}

5. Oxygen and hemoglobin concentration in blood flowing from frostbitten limbs.

These determinations were made on samples of blood withdrawn from the anterior tibial vein following immersion of the foot for 3 minutes

TABLE IX

Venous and arterial blood hemoglobin concentration and oxygen content following severe cold injury

\begin{tabular}{|c|c|c|c|c|c|c|}
\hline \multirow{2}{*}{$\begin{array}{l}\text { Animal } \\
\text { number }\end{array}$} & \multirow{2}{*}{$\begin{array}{c}\text { Time } \\
\text { after } \\
\text { frost- } \\
\text { bite }\end{array}$} & \multirow{2}{*}{$\begin{array}{c}\text { Foot } \\
\text { volume } \\
\text { incrase }\end{array}$} & \multicolumn{2}{|c|}{ Oxygen content } & \multicolumn{2}{|c|}{ Hemoglobin } \\
\hline & & & Venous & Arterial & Venous & Arterial \\
\hline 5 & $\begin{array}{r}\min . \\
0 \\
15 \\
60\end{array}$ & $m l$. & $\begin{array}{c}\text { vol. } \\
\text { per cent } \\
14.9 \\
16.4 \\
16.9\end{array}$ & $\begin{array}{c}\text { vol. } \\
\text { per cent } \\
17.9\end{array}$ & $\underset{\text { per cent }}{\text { grams }}$ & $\begin{array}{l}\text { grams } \\
\text { per cent }\end{array}$ \\
\hline 11 & $\begin{array}{r}0 \\
97 \\
115 \\
135 \\
150 \\
210 \\
232 \\
265 \\
294\end{array}$ & 37 & $\begin{array}{l}11.4 \\
18.1 \\
16.6 \\
13.8 \\
13.0\end{array}$ & $\begin{array}{l}14.8 \\
17.0 \\
16.1 \\
16.3\end{array}$ & & \\
\hline 4 & $\begin{array}{r}0 \\
20 \\
33 \\
44 \\
59 \\
68 \\
78 \\
147 \\
158\end{array}$ & $\begin{array}{r}0 \\
6 \\
15\end{array}$ & $\begin{array}{l}15.5 \\
21.4 \\
23.9 \\
15.5\end{array}$ & $\begin{array}{l}17.6 \\
21.9 \\
18.9 \\
18.1 \\
22.0\end{array}$ & & \\
\hline 3 & $\begin{array}{r}0 \\
26 \\
46 \\
58 \\
62 \\
76 \\
96 \\
183 \\
211 \\
268 \\
316\end{array}$ & $\begin{array}{l}14 \\
18 \\
21\end{array}$ & $\begin{array}{l}14.8 \\
16.2 \\
17.2 \\
19.2 \\
19.1 \\
19.3\end{array}$ & $\begin{array}{l}16.2 \\
18.1 \\
22.4 \\
21.8 \\
20.0 \\
19.7\end{array}$ & $\begin{array}{l}14.1 \\
15.2 \\
15.2 \\
17.2 \\
17.0 \\
16.9\end{array}$ & $\begin{array}{l}14.1 \\
14.0 \\
14.9 \\
16.4 \\
16.1\end{array}$ \\
\hline 13 & $\begin{array}{r}0 \\
20 \\
37 \\
56 \\
68 \\
80 \\
163 \\
174 \\
198 \\
223\end{array}$ & $\begin{array}{l}\mathbf{0} \\
2\end{array}$ & $\begin{array}{l}13.7 \\
15.4 \\
16.1\end{array}$ & $\begin{array}{l}16.6 \\
17.2 \\
18.0 \\
\\
18.0 \\
19.2 \\
16.9\end{array}$ & $\begin{array}{r}14.8 \\
14.9 \\
15.9 \\
16.1 \\
15.8\end{array}$ & $\begin{array}{l}14.3 \\
14.8 \\
15.8\end{array}$ \\
\hline 7 & $\begin{array}{r}0 \\
133 \\
186 \\
203 \\
223 \\
246\end{array}$ & $\begin{array}{r}0 \\
4 \\
\\
14 \\
16\end{array}$ & $\begin{array}{l}18.2 \\
18.2 \\
16.2\end{array}$ & $\begin{array}{l}19.0 \\
21.9 \\
22.0\end{array}$ & $\begin{array}{l}17.4 \\
18.9 \\
16.9\end{array}$ & $\begin{array}{l}16.8 \\
17.3 \\
17.4\end{array}$ \\
\hline
\end{tabular}


at $-55^{\circ} \mathrm{C}$. In a number of instances arterial samples were also obtained for comparison.

When serial samples of blood were taken, it was necessary to withdraw only very small volumes of blood in order that the blood volume be altered as little as possible. This was done by drawing blood directly from the vein into a Roughton-Scholander (20) blood pipette (1.0 to $1.5 \mathrm{~mm}$. bore, containing $100 \mathrm{cmm}$.) which was first wet with heparin solution $(10 \mathrm{mgm}$. per $\mathrm{ml}$.). The pipette was fitted to a 26-gauge hypodermic needle by means of a rubber gasket in the needle hub. The pressure in the vein was sufficient to fill the pipette. After removal of the needle, samples of blood for the determination of hemoglobin $(20 \mathrm{cmm}$.) and specific gravity (20 $\mathrm{cmm}$.) were transferred directly to appropriate pipettes, enough blood being left in the original pipette for determination of oxygen content by the method of Roughton and Scholander (20).

The results of these determinations are given in Table IX. Data for an individual animal (No.
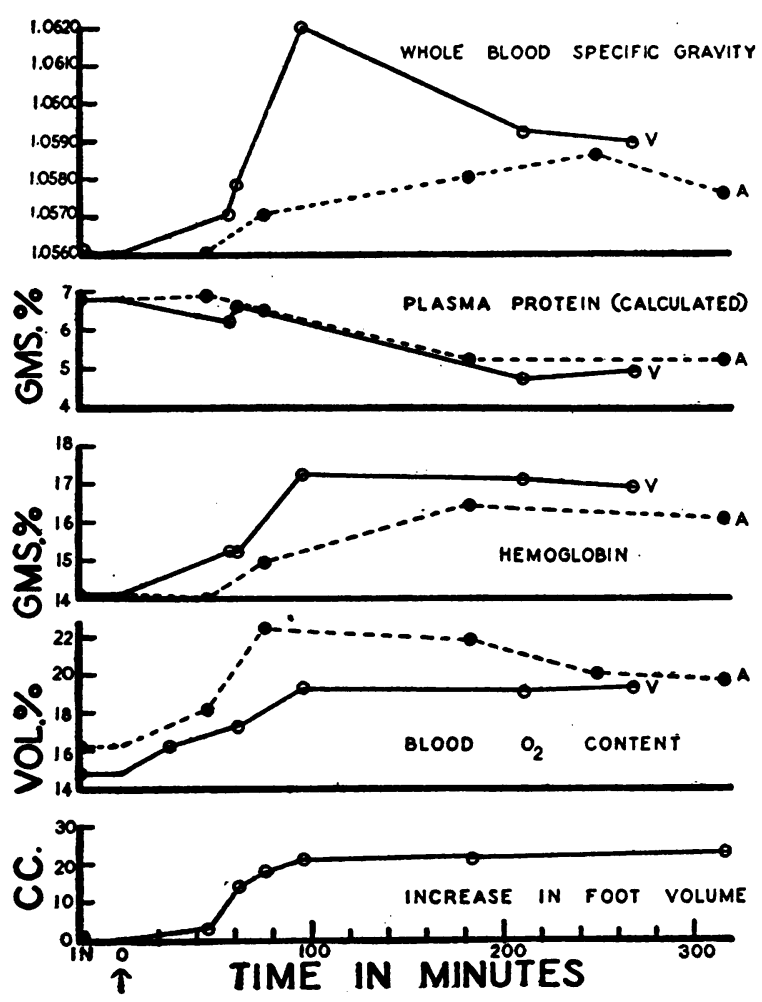

Fig. 6. Time Course of Changes in Whole Blood Specific Gravity, Plasma Protein, Hemoglobin, Blood Oxygen Content, and Foot Volume After Severe Cold Injury of One Hind Foot

Representative data from one animal after immersion of one foot at $-55^{\circ} \mathrm{C}$. for 3 minutes.

Solid lines........venous whole blood or plasma

Broken lines.......arterial whole blood or plasma
3) are plotted in Figure 6. As swelling of the injured leg occurs, the oxygen content of the venous blood flowing from the leg increases. In some cases the venous oxygen content actually exceeded the arterial oxygen content, due to loss of plasma in passage of the blood through the injured tissue. In all animals oxygen content of both venous and arterial blood increased during the period of swelling. In three animals (Nos. 3, 13, and 7) the hemoglobin concentration was also determined in the same blood samples in which oxygen content was determined.. By using a value for oxygen capacity of hemoglobin of $1.36 \mathrm{ml}$. per gram (18), the blood oxygen saturation has been calculated for different time periods after injury. These calculations all indicate that during the period of swelling the tissue of the injured limb is utilizing oxygen (that is, tissue death did not occur from the exposure at $-55^{\circ} \mathrm{C}$.). The data are not extensive enough to permit definite conclusions to be drawn as to whether oxygen utilization is decreased soon after injury. Such decrease in coefficient of oxygen utilization occurred in two of the three animals studied.

\section{DISCUSSION}

It has been pointed out that, following vascular occlusion of the rabbit ear prolonged enough to lead to gangrene of the part (9), the protein concentration of the edema fluid is almost identical with that occurring after frostbite. Likewise the protein concentration of edema fluid and the changes in hemoglobin and hematocrit reported here agree with those found by Harkins and Harmon (10) after freezing approximately one-quarter of the body surface of dogs. The early hemoconcentration observed to follow severe burning, which resembles that found in this series of animals following frostbite, has been observed by many workers in both animals and man $(11,12)$. Both the tissue edema fluid (21) and blister fluid (22) from burned areas have been demonstrated to be exudates with a protein concentration approaching that of plasma. Presman et al. (23) report the protein concentration of blister fluid taken from burned human beings to be about 70 per cent that of plasma. This is in good agreement with the value of 77 
per cent found in this series of animals after frostbite. The plasma protein changes following burning have been studied recently by Lischer et al. (24). Plasma albumin tended to fall in all animals, but plasma globulin fell only in less severely burned animals which survived. It has not been determined whether the fall in plasma protein following frostbite is due chiefly to decrease in the albumin fraction.

The significance of swelling, as one of the manifestations of injury following the exposure of parts of the body to severe cold, may be judged basically from two points of view: (a) its correlation with the extent of tissue loss and the course of healing; and (b) the information it may furnish concerning the nature of the injury produced. The experiments described above indicate that the magnitude of swelling alone is of relatively little help in affording a basis for describing the final outcome of injuries produced by cold. On the other hand, the rates of its appearance and its duration have a fairly consistent relation to the severity of injury. In those animals subjected to cold of sufficient degree and duration to produce complete gangrene and loss of the exposed part, the edema which appeared was more rapid in onset and disappearance than in the milder forms of injury. In no case did gangrene appear without the previous occurrence of massive edema in the injured region.

The demonstration that the fluid lost from the blood stream into the interstitial compartment of the injured regions contained large amounts of protein furnishes evidence of increased capillary permeability. Protein was found in quantities equalling that to be expected if as much as 77 per cent of the total volume of edema fluid were whole plasma. There occurred a massive loss of protein from the blood into injured feet and ears which recovered, as well as into those which became gangrenous. Thus, injury of capillaries sufficiently severe to induce increased permeability to plasma protein does not appear to be the determining event in the development of gangrene. However, the amounts of induration and persistent periarticular fibrosis which characterize the healing stage following injury by severe cold probably depend upon the protein centent of the edema fluid.
The loss of plasma from the blood stream during the course of swelling is sufficient to produce moderate increases in hemoglobin concentration and hematocrit during the first few hours after injury. Shock was not observed in any of the animals studied, probably because of the limited size of the injury. As plasma is lost into the injured region, the blood becomes diluted by fluid from the interstitial compartment and probably from the gut as well, so that the volume of fluid lost to the frostbitten part is greater than the quantity by which the plasma volume is reduced. While the replacement of plasma volume is sufficient to produce a fall in plasma protein concentration during the first few hours after injury, it is not enough to compensate completely for the fluid loss, and a moderate increase in hematocrit occurs.

\section{SUM MARY}

Following severe cold injury, produced by immersion of one hind foot of rabbits in liquid at $-55^{\circ} \mathrm{C}$. for 3 minutes, massive local edema of the part is an inevitable consequence. Investigation of the specific details involved in the development of the edema permit the following conclusions to be drawn.

1. Swelling of the foot begins as soon as thawing is complete and reaches a maximum in about 6 hours. Decrease in volume begins about 24 hours after injury and continues progressively during the next 5 days until the foot dries and becomes mummified. The maximum foot volume is about 3 times the initial volume.

2. Subcutaneous tissue pressure in frostbitten feet increases as the feet swell, until a pressure of about $25 \mathrm{~cm} . \mathrm{H}_{2} \mathrm{O}$ is attained 4 to 6 hours after injury at a time when the volume of the feet is maximal.

3. Fluid withdrawn from frostbitten feet during the stage of maximal edema and fluid from blisters on frostbitten ears contain an average of 4.3 per cent protein. The protein concentration of the fluid decreases progressively with time after injury.

4. The presence of toxic materials in the edema fluid was not indicated by the following tests: application to isolated guinea pig and fowl intestinal smooth muscle; intradermal injection in- 
to rabbit ears; intravenous administration to rabbits while arterial pressure was being recorded.

5. The mean protein concentration of edema fluid from frostbitten feet is equivalent to about 76 per cent of the protein concentration in plasma before injury.

6. Plasma protein concentration is reduced during the first 6 hours after injury but is restored after 24 hours.

7. Moderate increases in hematocrit and hemoglobin concentration of the blood occur during the period of swelling of the foot.

8. Calculation of the extent to which fluid lost into the injured limb is replaced by extravascular fluid indicates that plasma volume is first reduced and then progressively restored during the first 6 hours after injury. Determination of plasma volume by the dye method in four animals before and after injury agrees with the plasma volume changes calculated on the basis of changes in concentration of blood constituents.

9. During the period of swelling, loss of fluid consisting of about 76 per cent plasma is rapid enough to result in decrease in plasma volume. Progressive replacement of plasma volume during the first few hours after injury is sufficient to result in a fall in plasma protein cencentration, but is not great enough to compensate completely for the fluid loss to the foot; thus, moderate increase in hematocrit occurs.

10. In some cases oxygen content of venous blood draining from the injured limb during swelling exceeded arterial oxygen content due to loss of fluid into the injured area. Oxygen utilization by the injured limb occurs during the first 5 hours after injury.

\section{BIBLIOGRAPHY}

1. Fuhrman, F. A., and Crismon, J. M., Studies on gangrene following cold injury. I. A method for producing gangrene by means of controlled injury by cold. J. Clin. Invest., 1947, 26, 229.

2. Fuhrman, F. A., and Crismon, J. M., Studies on gangrene following cold injury. II. General course of events following cold injury of rabbit feet and ears. J. Clin. Invest., 1947, 26, 236.

3. Henderson, Y., Adventures in Respiration. The Williams and Wilkins Co., Baltimore, Md., 1938, p. 243.

4. Wells, H. S., Youmans, J. B., and Miller, D. G., Jr.,
Tissue pressure (intracutaneous, subcutaneous and intramuscular) as related to venous pressure, capillary filtration and other factors. J. Clin. Invest., 1938, 17, 489.

5. Landis, E. M., The capillary blood pressure in mammalian mesentery as determined by the microinjection method. Amer. J. Physiol., 1930, 93, 353.

6. Landis, E. M., Capillary pressure and capillary permeability. Physiol. Rev., 1934, 14, 404.

7. Barbour, H. G., and Hamilton, W. F., The falling drop method for determination of specific gravity. J. Biol. Chem., 1926, 69, 625.

8. Weech, A. A., Reeves, E. B., and Goettsch, E., The relationship between specific gravity and protein content in plasma, serum, and transudate from dogs. J. Biol. Chem., 1936, 113, 167.

9. Pochin, E. E., Oedema following ischaemia in the rabbit's ear. Clin. Sci., 1942, 4, 341.

10. Harkins, H. N., and Harmon, P. H., Thermal injuries; the effects of freezing. J. Clin. Invest., 1937, 16, 213.

11. Harkins, H. N., The Treatment of Burns. Charles C. Thomas, Springfield, Ill. and Baltimore, Md., 1942.

12. Harkins, H. N., The present status of the problem of thermal burns. Physiol. Rev., 1945, 25, 531.

13. Barsoum, G. S., and Gaddum, J. H., The pharmacological estimation of adenosine and histamine in blood. J. Physiol., 1935, 85, 1.

14. Anrep, G. V., Barsoum, G. S., Talaat, M., and Wieninger, E., Further observations upon the release of histamine by skeletal muscles. J. Physiol., 1939, 96, 240.

15. Kellaway, C. H., and Rawlinson, W. A., Studies on tissue injury by heat. III. Isolated limb preparations. Austral. J. Exper. Biol. Med. Sci., 1944, 22, 83.

16. Shorr, E., Zweifach, B. W., and Furchgott, R. F., On the occurrence, sites, and modes of origin and destruction, of principles affecting the compensatory vascular mechanism in experimental shock. Science, 1945, 102, 489.

17. Phillips, R. A., Van Slyke, D. D., Dole, V. P., Emerson, K., Hamilton, P. B., and Archibald, R. M., Copper sulfate method for measuring specific gravities of whole blood and plasma. U. S. Navy Res. Unit, Hosp. of Rockefeller Inst. Med. Res., New York.

18. Bernhart, F. W., and Skeggs, L., The iron content of crystalline human hemoglobin. J. Biol. Chem., 1943, $147,19$.

19. Hopper, J., Tabor, H., and Winkler, A. W., Simultaneous measurements of the blood volume in man and dog by means of Evans blue dye, T-1824, and by means of $\mathrm{CO}$; normal subjects. J. Clin. Invest., 1944, 23, 628.

20. Roughton, F. J. W., and Scholander, P. F., Micro gasometric estimation of the blood gases. I. Oxygen. J. Biol. Chem., 1943, 148, 541. 
21. Beard, J. W., and Blalock, A., Experimental shock. VIII. The composition of the fluid that escapes from the blood stream after mild trauma to an extremity, after trauma to the intestines and after burns. Arch. Surg., 1931, 22, 617.

22. McIver, M. A., A study in extensive cutaneous burns. Ann. of Surg., 1933, 97, 670.
23. Presman, D. L., Janota, M., Weston, R. E., Levinson, S. O., and Necheles, H., Intensive human serum treatment of burn shock and a modified formula for calculating the amount of infusion. J. A. M. A., 1943, 122, 924.

24. Lischer, C., Elman, R., and Davey, H. W., Experimental burns. III. Changes in plasma albumin and globulin. War Med., 1944, 5, 43. 